\title{
School museums as dynamic areas for widening the heuristic potential and the socio-cultural impact of the history of education. A case study from Italy
}

\section{Anna Ascenzi, Marta Brunelli \& Juri Meda}

To cite this article: Anna Ascenzi, Marta Brunelli \& Juri Meda (2019): School museums as dynamic areas for widening the heuristic potential and the socio-cultural impact of the history of education. A case study from Italy, Paedagogica Historica, DOI: $10.1080 / 00309230.2019 .1660387$

To link to this article: https://doi.org/10.1080/00309230.2019.1660387

Published online: 10 Dec 2019.

Submit your article to this journal $₫$

Q View related articles ๘

View Crossmark data $₫$ 


\title{
School museums as dynamic areas for widening the heuristic potential and the socio-cultural impact of the history of education. A case study from Italy
}

\author{
Anna Ascenzi (D), Marta Brunelli (D) and Juri Meda (iD) \\ Department of Education Sciences, Cultural Heritage and Tourism, University of Macerata, Macerata, Italy
}

\begin{abstract}
The contribution aims at introducing some points to reflect on the new role which university museums of schools and education can play today in the wake of current international processes of revitalisation of university heritage and museums, particularly in the light of the new objectives of the University Third Mission. Starting from the experience of the "Paolo and Ornella Ricca" School Museum in Macerata University, the authors illustrate how university museums can achieve several goals: on the one hand, to foster the opening up of the universities and academic research towards civil society, and the dissemination of the results of the most innovative historical-educational research; on the other hand, to promote the meaning and the value of the educational heritage as a collective cultural asset able to give participation and knowledge; finally, to make the historical-educational disciplines more valuable as a specialised knowledge which, through such heritage, can express a new specificity and a more active role within academic community.
\end{abstract}

\section{ARTICLE HISTORY}

Received 21 January 2019 Accepted 11 June 2019

\section{KEYWORDS}

University museums; educational heritage; cultural transfer; public engagement; history of education

\section{Introduction}

We live in an era of ever-faster changes, which are radically altering the world we knew in its demographic, economic, social and cultural structures. This process inevitably affects the institutions where we act as scholars and educators, allowing us to daily perceive their tangible effects both at school and at university. Every day we see how the ever more pervasive use of new technologies is changing the way we create and transmit knowledge, transforming learning styles of the new learners or undermining traditional teaching models, and so on. But we also see the emergence of new educational needs, for example those related to the evolution of fundamental values and ideas such as "citizenship", "inclusion" or "democratic participation", which - during the era of the so-called Liquid modernity ${ }^{1}$ - are subject to a constant change and recontextualisation of social, political and cultural nature.

CONTACT Marta Brunelli marta.brunelli@unimc.it Department of Education Sciences, Cultural Heritage and Tourism, University of Macerata, Polo Bertelli 1 (C.da Vallebona), Macerata 62100, Italy

${ }^{1}$ Zygmunt Bauman, Liquid Modernity (Cambridge: Polity, 2000).

(C) 2019 Stichting Paedagogica Historica 
But, if the educational agencies par excellence - such as schools and universities are looking for new educational models ${ }^{2}$ which replace traditional instructional and disciplinary objectives with the new ones aimed at forming new citizens (i.e. by creating "well-made heads" instead of "full heads" ${ }^{3}$ ), the same change equally applies to other cultural and educational institutions, such as museums. As heritage institutions par excellence and informal educational players devoted to lifelong learning at the same time, today museums are also proposing new organisational models, languages and services able to respond to the increasingly complex cultural, educational and social needs of the contemporary world. ${ }^{4}$

These initial reflections allow us to more specifically contextualise the challenges which contemporary museums are claimed to address, including university museums. Among these, there are also the university historical-educational museums, which are the object of this contribution. Placed at the confluence between two realities - the university, of which they are an expression, and the world of public museums university museums now have to rethink their mission and their role inside and outside academy. For the educational museums in particular, this means not only to overcome some specific critical issues, but also to capture a lot of opportunities which are inherent to their particular nature, as we will see.

\section{Increasing importance of the university heritage and museums}

In this historical context, in fact, we are witnessing the emergence of a specific potential for university museums, which have increasingly become in recent years a privileged space for didactic innovation, applied research and, finally, for interplay between public and academic engagement. This challenging but also exciting season of cultural and social revitalisation of university museums is the result of the convergence between two fundamental phenomena, the evolution of which it will be enlightening here to summarise.

\subsection{The university heritage as a component of the European cultural heritage}

The first phenomenon is represented by the unprecedented growing interest in university heritage (and the museums which preserve it), which has strengthened at the

\footnotetext{
${ }^{2}$ Regarding the adaptation of the European educational systems to meet the goals in the strategic framework "Education and Training 2020" (work programme ET2020), see the communications of the European Commission COM/2016/0941: Improving and Modernizing Education, Bruxelles, 7.12.2016, and Com(2017)248: School Development and Excellent Teaching for a Great Start in Life, Bruxelles, 30.5.2017, in addition to the report ET 2020 Working Group on Schools, European Ideas for Better Learning. The Governance of School Education Systems (Bruxelles: EC-DirectorateGeneral Education, Youth, Sport and Culture Schools and Multilingualism, 2018). With regard to European university policies, see European Commission High-Level Group on the Modernisation of Higher Education, Report to the European Commission on New Modes of Learning and Teaching in Higher Education (Luxembourg: Publications Office of the European Union, October 2014).

${ }^{3}$ Edgar Morin, La tête bien faite (Paris: Seuil, 1999). The edition referred to is: La testa ben fatta (Milano: Raffaello Cortina, 2000), 15-29.

${ }^{4}$ Regarding the renewed educational role of museums in the new scenarios opened up by innovations, such as the new technologies or multicultural society etc., it is worth mentioning the results of some particularly significant European projects: the report Mu.SA Project, Museum of the Future, Roma, Symbola Foundation, 2017, http://www.project-musa. eu; the project MeLa-European Museums in an Age of Migration, http://www.mela-project.polimi.it/; and the LEM Museum Report 7: New Trends in Museums of the 21st Century. The Learning Museum Network Project, ed. Ann Nicholls, Manuela Pereira and Margherita Sani, 2013, http://online.ibc.regione.emilia-romagna.it///libri/pdf/LEM7th-report-newtrends-in-Museums-of-the-21st-century.pdf (accessed 10 December 2018).
} 
beginning of the new millennium as the result of a global cultural and institutional mobilisation against the general crisis of identity and resources which university museums had been through in the previous decades. ${ }^{5}$ When the Council of Europe launched the campaign Europe, a Common Heritage (1999-2000) in 1999, in fact, among the five transnational projects co-funded by the Council of Europe and the European Commission, one was devoted to the heritage of European universities, recognised as one of the essential aspects of European history and culture. In the volume published at the end of that project, not only were the wealth and variety of the European university heritage and its relevance for both the academic and social communities brought to the attention of the public, but also peculiar critical issues related to its conservation, management and restoration were highlighted. ${ }^{6}$ Consistently with this expression of interest, two important bodies were born in that same period: at an international level, the thematic Commission for University Museums and Collections (UMAC ${ }^{7}$ ) was established within the ICOM-International Council of Museums in 2000; at a European level, the European Academic Heritage Network UNIVERSEUM was born: an inter-university network inspired by the Halle Declaration of 2000, and aimed at enhancing access to and use of European university collections by students, academics and a broad public. At the end of this process, in 2005, the Committee of Ministers of the Council of Europe approved the Recommendation No R (2005) 13 on the governance and management of university heritage, with which university administrations were asked to finally assume legal, administrative and moral responsibility for their own heritage. ${ }^{8}$

\subsection{Museums and the Third Mission of the university}

Besides this growing awareness about the university heritage value, in the same years another phenomenon in Europe was developing, which would have had a major impact on the academic world and, consequently, on museums too. We refer to the so-called "Second Academic Revolution", 9 which, beginning around the 1980s, has seen universities facing new demands from the knowledge society and knowledge-based economy. In order to respond to financial and economic pressures from changing environments, the concept of the Third Mission (or Third Stream) arose, which - in addition to the

\footnotetext{
${ }^{5}$ Marta Lourenço, "Where Past, Present and Future Knowledge Meet: An Overview of University Museums and Collections in Europe", Museologia Scientifica. Memorie 2 (2008): 321-9.

${ }^{6}$ Nuria Sanz and Sjur Bergan, eds., The Heritage of European Universities (Strasbourg: Council of Europe, 2002). Nowadays, the volume is available in the II edition of 2007.

${ }^{7}$ See the institutional website of UMAC-University Museums And Collections, http://umac.icom.museum (accessed 10 December 2018). Since 2001, the commission has been running a Worldwide Database of University Museums and Collections, which is constantly updated and allows us to appreciate the extreme richness and variety of "Institutional Types" into which universities have organised their museums, collections and heritage. See the database's site, http:// university-museums-and-collections.net/ (accessed 10 December 2018).

${ }^{8}$ Council of Europe, Recommendation Rec (2005) 13 of the Committee of Ministers to Member States on the Governance and Management of University Heritage. Adopted by the Committee of Ministers on 7 December 2005 at the 950th meeting of the Ministers' Deputies. It should be noted that the question of a proper management of university heritage and collections in Italy had already been raised by the Museum Commission of the CRUI (Conference of Italian University Rectors) in 1999. See Giacomo Giacobini, "J'accuse. ..! (con il dovuto rispetto). I musei universitari, la CRUI e le occasioni perdute", Museologia Scientifica 10 (2016): 15-20.

${ }^{9}$ Henry Etzkowitz and Andrew Webster, "Entrepreneurial Science: The Second Academic Revolution", in Capitalizing Knowledge: New Intersections of Industry and Academia, ed. Henry Etzkowitz, Andrew Webster and Peter Healey (Albany: SUNY Press, 1998), 21-46.
} 
traditional missions of Teaching and Research - was initially intended as all those "activities concerned with the generation, use, application and exploitation of knowledge and other university capabilities outside academic environments". ${ }^{10}$ Over the years, the Third Mission has become an increasingly ambiguous term and has provoked an international debate, giving birth to a vast literature ${ }^{11}$ that resulted in a variety of interpretive models and indicators differing from each other ${ }^{12}$ and constantly evolving - as shown by the recent reflection on the so-called Fourth Mission. ${ }^{13}$

Despite the "fluidity" of its conceptualisation, the Third mission has become especially in the wake of the European Lisbon Council - a strategic focus for higher education policies of the European Union ${ }^{14}$ and a framework for the development of university policies in all member countries. For this reason, here the authors will take as a reference the guidelines elaborated in Italy by ANVUR (the Italian Agency for University Research Evaluation), which, since 2004, has defined the Third Mission as "the propensity of [higher education] structures to open up to the socio-economic context through the economic value-enhancing of knowledge, and through the transfer of knowledge". ${ }^{15}$ More specifically ANVUR, after highlighting that the Third Mission may take different forms, depending on the disciplinary focus of each higher education institution as well as its territorial context, considered it appropriate to group objectives and activities of the Third Mission into two dimensions: ${ }^{16}$

(1) A "Third Mission of economic valorisation of knowledge", aimed at translating the research findings into goods and services such as: intellectual property, university entrepreneurship (spin-offs), consultancy and research for third parties, mediation agencies and technology transfer offices;

${ }^{10}$ Jordi Molas-Gallart et al., Measuring Third Stream Activities: Final Report to the Russell Group of Universities (Brighton: Science and Technology Policy Research Unit - University of Sussex, 2002), here: IV.

${ }^{11}$ This is not the place for a full-dress discussion of the literature, about which readers may refer to more specific contributions such as, for example, the review by Rómulo Pinheiro, Patricio V. Langa and Attila Pausits, "One and Two Equals Three? The Third Mission of Higher Education Institutions", European Journal of Higher Education 5, no. 3 (2015): 233-49.

${ }^{12}$ See for example Jordi Molas-Gallart and Elena Castro-Martínez, "Ambiguity and Conflict in the Development of 'Third Mission' Indicators", Research Evaluation 16, no. 4 (2007): 321-30; Philippe Laredo, "Revisiting the Third Mission of Universities: Toward a Renewed Categorization of University Activities?", Higher Education Policy 20 (2007): 441-56. This is the context in which the European project E3M-European Indicators and Ranking Methodology for University Third Mission was financed, http://www.e3mproject.eu/ (accessed 8 October 2018). On the Italian scenario: Stefano Boffo and Roberto Moscati, "La Terza Missione dell'università. Origini, problemi e indicatori", Scuola Democratica 2 (2015): 251-67.

${ }^{13}$ This recent approach presents a special focus on co-creation of sustainable development based on a process of circular exchange of knowledge (instead of a linear process of knowledge transfer) between university and government, industry and civil society. See: Gregory Trencher et al., "Beyond the Third Mission: Exploring the Emerging University Function of Co-Creation for Sustainability", Science and Public Policy 41, no. 2 (2014): 151-79.

${ }^{14}$ European Commission, "Communication from the Commission: The Role of the Universities in the Europe of Knowledge", COM (2003) 58 final (Brussels: European Commission, 5 February 2003); European Commission, "Mobilising the Brainpower of Europe: Enabling Universities to Make their Full Contribution to the Lisbon Strategy", COM (2005) 152 final (Brussels: European Commission, 20 April 2005); Council of Europe, Declaration on the Responsibility of Higher Education for Democratic Culture, 23 June 2006; and OECD, Higher Education and Regions: Globally Competitive, Locally Engaged (Paris: OECD Publications, 2007).

${ }^{15}$ This definition appeared since the first public evaluation procedures (VQR 2004-2010; VQR 2011-2014) implemented by the national Agency (ANVUR). The same definition in: ANVUR, Manuale per la valutazione della terza missione delle università italiane, 2015 (here: 4).

${ }^{16}$ Such a distinction is still operating in the recent documents: ANVUR, Linee guida per la compilazione della Scheda Unica Annuale Terza Missione e Impatto Sociale (SUA-TM/IS) per le Università (Roma: Anvur, 7 November 2018), here: 4; and ANVUR, Rapporto Biennale sullo Stato del Sistema Universitario e della Ricerca. Sezione 9: attività di Terza Missione (Roma: Anvur, 2018), here: 494-503. 
(2) A "Third Mission of cultural and social nature", oriented to the "production of public goods which increase the well-being of society" and consisting of products and activities: (1) with cultural content, i.e. focused on the management of heritage and the production of cultural activities (museums, archaeological excavations, archives and libraries, cultural events, musical activities etc.); (2) with social value (public health protection); (3) with educational value (school education, continuing education, competences certification, MOOC); (4) with a content of public awareness (i.e. public debates, dissemination of scientific expertise, public events, public access to university heritage, participatory democracy initiatives etc.). These last activities, in particular, fall under the umbrella term of Public Engagement, meant as a "complex of non-profit activities with educational, cultural and developmental value for society". ${ }^{17}$

Such a process (in Italy still under way) of progressive recognition of the Third Mission in the procedures for the Evaluation of Research Quality for the first time helped shine a new light on university heritage and museums. Especially museums - once considered marginal (or useless) in comparison to academic research and teaching - have emerged as key structures and functional to interact with external society and to create a cultural, economic and social value for the community. Under these urgent requests, university museums are thus experiencing a season of real revitalisation, as the Italian specialists in the field testify:

It was time that Italian universities became aware of the enormous cultural heritage they possess; it was time that the universities emancipated the riches concealed in the ghetto in which they had relegated them; it was time that Chancellors, Deans and Professors acknowledged the museums that had managed to survive within their universities; it was time that enlightened Chancellors understood the importance of collections assembled during decades and sometimes centuries of research by their scientists; it was time that space was reallocated to university museums, space that in the past had been slowly taken away from them; it was time that university museums were managed by well-trained curatorial staff and not seen merely as parking lots for researchers awaiting positions or even unproductive ones. [...] All this is leading university museums to become a fundamental link between science and society precisely within the context of the third mission of universities. ${ }^{18}$

If such a scenario presents unquestionable opportunities for university museums, nevertheless it compels them to redefine their functions and develop strategic actions which currently appear to focus on three axes: (1) enhancing the university heritage as a resource for research and teaching; (2) promoting the knowledge of the heritage inside and outside the university; (3) acting as places for meeting and active involvement of all the members of society.

\footnotetext{
${ }^{17}$ ANVUR, Manuale per la valutazione della terza missione delle università italiane, cit. (here: 42). However, it should be noted that the $3 \mathrm{M}$ indicators, especially those related to public engagement, are still poorly standardised (Valentina Martino, "Terza Missione e cultura delle università. Note per una sociologia del patrimonio accademico", Rivista Trimestrale di Scienza dell'Amministrazione 1 (2018), http://www.rtsa.eu/RTSA_1_2018_Martino.pdf (accessed 10 December 2018).

${ }^{18}$ Vincenzo Vomero, "La terza missione dell'Università, prima missione per i Musei", Museologia Scientifica. Nuova Serie 10 (2016): 9-14 (here: 9).
} 


\section{Revitalisation process for university heritage: trends and critical issues}

As we have seen, the same phenomena and processes, which have put higher education institutions at the centre of many debates at international level, have also opened a season of rebirth and revitalisation for university museums. Emblematic of this trend is the increasing number of national and international conferences on this topic which have been held under the impetus of ICOM and especially of UMAC and UNIVERSEUM: protagonists, in recent years, of a lively debate on the new role that museums - and of course also university museums - should play in the twenty-first century. ${ }^{19}$ Within the framework just outlined, however, it seems appropriate to identify certain trends and critical areas emerging, at international level as well as in Italy, so that all those involved with the management of university museums, and in particular of museums of education, can be mindful of both the challenges to face and the opportunities to grasp.

\subsection{The leadership of science museums in the university scenario}

Today, this important movement of revitalisation of the rich heritage of universities worldwide is mainly led by the science museums, for various reasons.

The first reason is represented by their number and their widespread diffusion. In fact, in all the scientific universities, especially in the oldest ones, there are important collections of natural sciences, medicine and scientific instruments. At an Italian level, this relevance is confirmed by the recent survey conducted by the Department of Communication and Social Research at the University of Rome "La Sapienza" 20 and, at an international level, by the nature of the university museums registered in the UMAC database. ${ }^{21}$ This considerable scientific heritage - which, after losing its usability and assuming the status of historical heritage, had been considered for a long time as a pile of "relics to be venerated" 22 and a research area only for the historians of science - is currently of utmost interest to universities, which see it as a precious resource for the Third Mission.

The second reason lies in the renewal of science communication, which the science museums have implemented in the latest 30 years. As a consequence, today the university science museums are facilitated by the extraordinary evolution that Scientific Museology has experienced, especially after the "boom" of new Science Centres between the 1980s and the 1990s definitely changed the languages and the exhibition models of science museums, ${ }^{23}$ and

\footnotetext{
${ }^{19}$ In this regard, the forthcoming 19th Annual UMAC Conference, which will be held within the 25th ICOM General Conference in Kyoto (September 2019), will be precisely dedicated to: "University Museums and Collections as Cultural Hubs: The Future of Tradition".

${ }^{20}$ Valentina Martino, "Musei e collezioni del patrimonio universitario. Indagine su un sistema culturale diffuso", Museologia Scientifica. Nuova Serie 10 (2016): 42-55.

${ }^{21}$ Of the museums registered $57 \%$ are represented by science museums. This percentage is made up of Natural History and Natural Science museums (33.3\%), Science and Technology museums (14.1\%) and, finally, Medicine museums (10.1\%). These data were consulted on 18 August 2018. It must be noted that participating in the database is voluntary, so the data should be understood as indicative and not exhaustive.

${ }^{22}$ Pasquale Tucci, "L'evoluzione storica del museo scientifico, dalle gallerie alla rete", Bollettino del Cilea 102 (2006): 7-10.

${ }^{23}$ Luigi Amodio, Annalisa Buffardi, and Lello Savonardo, eds., La cultura interattiva: comunicazione scientifica, musei, science centre (Pomigliano d'Arco, NA: Oxiana, 2005); Vincenzo Vomero, "Le mutazioni della museologia scientifica", Museologia Scientifica. Nuova Serie 1 (2007): 13-15; and Matteo Merzagora and Paola Rodari, La scienza in mostra. Musei, science centre e comunicazione (Milano: FrancoAngeli, 2007).
} 
assigned to the scientific heritage an educational and communicative function able to break down the barriers between the community of scientists and society. ${ }^{24}$

In this context, it is clearer why the science museums play a leading role in the whole university museum reality, which - also in Italy - in the latest years has experienced a season of revival, renewal and opening (or re-opening) to the public of many structures. $^{25}$ In fact, especially after the ANVUR, as mentioned, recognised museums as tools for the Third Mission, today we are witnessing in Italian universities the birth of poli museali, i.e. university museum systems which respond to different purposes. On the one hand, they make it possible to centrally manage the university heritage, for example by merging scattered collections to create real museums, which can work as poles of attraction for cultural tourism and tools for the promotion of the territory. ${ }^{26}$ On the other hand, the museum systems especially strengthen the identity of the oldest universities which - being historical universities and research universities at the same time - rely not only on the quality of the research developed and the services provided but also on a long-standing tradition in order to promote their image ${ }^{27}$ among various stakeholders: from schools and families (the natural catchment area for future students) to economic, political and cultural organisations and groups of civil society.

\subsection{The renaissance of humanities museums: finding a role for educational museums}

Of course, in Italian universities there are many and equally prestigious museums of humanities too, such as art museums and galleries, archaeological museums and plastercast galleries $^{28}$ and so on. Many of these museums are similarly experiencing the positive effects of the trends outlined above and the consequent renovation of the university museum centres and structures. ${ }^{29}$ This trend has been captured by the aforementioned

\footnotetext{
${ }^{24}$ Regarding the new modalities of public communication of science and science education in the so-called "postacademic era of science" see Pietro Greco, "Il modello Venezia. La comunicazione nell'era post-accademica della scienza", in La comunicazione della scienza. Atti del l e Il Convegno Nazionale, ed. Nico Pitrelli and Gianluca Sturloni (Roma: Zadigroma Editore, 2004), 11-35.

${ }^{25}$ Among the many cases, it is possible to mention the university museum system in Padua as an example. Led by a University Museum Centre established in 2002, the Padua case is of particular interest because of the number and antiquity of its museums. Notwithstanding the establishment in 1993 of a prestigious Museum of Education, the greater and oldest part of the museums is represented by Science museums (such as Anatomy, Physics, Geology and Palaeontology etc.), many of which have been (or are being) renovated in spaces and arrangements just in these years.

${ }^{26}$ See the considerations regarding the case of the Museum Centre at the University of Pavia in: Fabio Bevilacqua and Maurizio E. Maccarini, "Il business plan del Sistema Museale d'Ateneo dell'Università di Pavia", in Marketing culturale. Valorizzazione di istituzioni culturali. Strategie di promozione del territorio, ed. Silvia Luraghi and Paola Stringa (Milano: FrancoAngeli, 2006): 69-83.

${ }^{27}$ Regarding the role of the so-called "reputation capital" in university marketing, please see the contributions collected in Alessandra Mazzei, ed., Comunicazione e reputazione nelle università (Milano: FrancoAngeli, 2004).

${ }^{28}$ With regard to university plaster casts and ancient art galleries, which in the last 15 years have equally been the subject of renewed interest in Italy, see the Italian series of International conferences on Plaster Casts (started in 2006 at the Antonio Canova Museum in Possagno and now in its fourth edition), as well as the more recent university projects in Pavia (Anna Letizia Magrassi Matricardi, "La Raccolta archeologica e la Gipsoteca dell'Università di Pavia: un progetto museografico di apertura al pubblico e di valorizzazione", Annali di Storia delle università italiane 2017, no. 1 (2017): 167-76); and Simone Rambaldi, La Gipsoteca del Dipartimento Culture e Società dell'Università degli Studi di Palermo. Storia e Catalogo (Palermo: Palermo University Press, 2017).

${ }^{29}$ Regarding the revival and the renovation of university art museums carried out in universities such as Milan, Parma and Padua, see Milena Zanotti, "Vocazione museo: Arte e istituzioni cognitive", 15 July 2015, Giornale delle Fondazioni, http:// www.ilgiornaledellefondazioni.com/content/vocazione-museo-arte-e-istituzioni-cognitive (accessed 10 December 2018).
} 
survey on Italian university museums and collections, from which appears a remarkable humanistic heritage whose situation, however, is marked by lights and shadows. A strong point is represented by the emerging of innovative museums and exhibition models, such as widespread museums, university eco-museums and new exhibition genres related to artcollection events and temporary or permanent art installations. ${ }^{30}$ The weakness is that, at the moment, the humanistic heritage (although large and widespread) is the object of musealisation processes much slower than the scientific heritage, if we consider that humanities museums are $22 \%$ of those registered so far (see Table 1 )

For the purposes of the present paper it is relevant that, within the sub-set of Humanities museums, the category of "History, Philosophy, Pedagogy and Psychology" museums is quite far behind that of "Antiquity, Philology-literature, and Art history museum" (as illustrated in Table 1), with the "pedagogy museums" representing only $1.65 \%$ of the total university museums. In such a scenario, the museums of schools and education have to face and solve a series of critical issues which, being inherent to their particular nature, come on top of the challenges described above, that is to say:

(1) their low numerical importance, which risks letting them be "invisible" and so cut off from the university policies at national and international levels;

(2) the lesser importance attributed to such collections, considered a "minor heritage" compared to others (i.e. scientific, archaeological or historical-artistic heritage) which, instead, are more able to attract important public and private finance;

Table 1. University collections and museums by disciplinary area. Source: Martino, "Musei e collezioni del patrimonio universitario. Indagine su un sistema culturale diffuso", cit. (here: 49). Data re-elaborated by the authors.

Science
museums
$(75.1 \%)$$\left\{\begin{array}{l}\text { Biology (29\%) } \\ \text { Earth sciences (15.4\%) } \\ \text { Physics, chemistry, mathematics and } \\ \text { informatics (14.1\%) } \\ \text { Agricultural and veterinary sciences (8.3\%) } \\ \begin{array}{l}\text { Medicine (5.4\%) } \\ \text { Industrial and information engineering } \\ (2.1 \%) \\ \text { Civil and architectural engineering (0.8\%) }\end{array}\end{array}\right.$

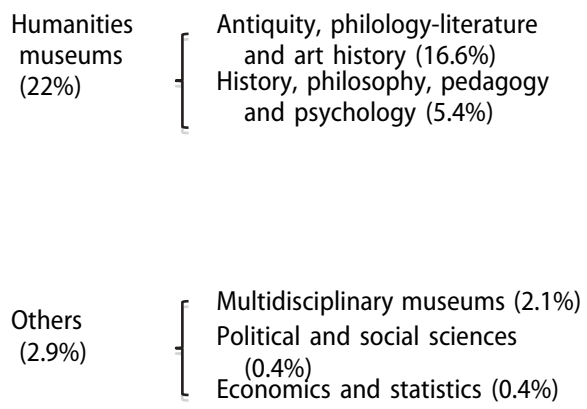

\footnotetext{
${ }^{30}$ Martino, "Musei e collezioni del patrimonio universitario. Indagine su un sistema culturale diffuso", cit. (here: 49-51). See also Isabella Mozzoni, Simone Fanelli and Chiara Carolina Donelli, "Italian University Collections: Managing the Artistic Heritage of the University's Ivory Tower", ENCATC Journal of Cultural Management and Policy 8, no. 1 (2018): 30-43.
} 
(3) and finally, the generalised prejudice that such museums are too narrowly focused on the disciplinary specificity of their collections and, for the same reason, are unable to play an active and innovative role, both inside and outside the university.

In conclusion, these are the challenges our historical-educational museums have to face, the most important being the risk of getting confined within a scientific-disciplinary field too often considered a "niche" and, therefore, not exploitable to achieve the objectives of the Third Mission.

\section{University museums of educational heritage: the Italian context}

The Italian scenario of the university educational heritage is emblematic since it is animated by realities which - despite the difficulties highlighted above - are proving to express a strong dynamicity and an interesting potential for development. As seen, in Italy the educational university museums and collections are a very small percentage: of an actual total of $242^{31}$ (198 museums and 44 collections $^{32}$ ), only 5 are focused on the history of school and the history of education. Nevertheless, in recent years - i.e. between the late 1980s and the first decades of 2000 - they have become the protagonists of a season similar to the one that the Spanish historian of education Ruiz Berrio ${ }^{33}$ had defined (for the Iberian area) as a phase of take-off and/or reconversion. ${ }^{34}$

This movement was led by the museum at Roma Tre University. Founded by the educationalist Mauro Laeng in 1986 as a Museum of History of Teaching, it had the merit of inheriting the legacy of the national Museum of Education and Schooling established in Rome by Ruggiero Bonghi in $1874,{ }^{35}$ on the one hand. On the other, it had the merit of reopening a dialogue between university and the educational heritage, and to some extent of reactivating the old (and, in Italy, unfortunate) season of those Pedagogical Museums which, after the middle of the nineteenth century, were set up as a tool at the service of university research and teaching, and aimed at the training of Italian teachers. ${ }^{36}$

After the Roman case, other research groups began investigating the educational heritage in several Italian universities, and gave life to university museums and collections. In primis, the group of academics should be remembered who in 1993 gave birth to the Museum of Education at the University of Padua, which now boasts a wide heritage ranging from school education to family, extra-school and children's

\footnotetext{
${ }^{31}$ These data, from the Italian census by the University of Rome "La Sapienza" (Martino, "Musei e collezioni del patrimonio universitario. Indagine su un sistema culturale diffuso", cit.), are close to the UMAC census, which registers 233 university museums and collections in Italy (see: http://university-museums-and-collections.net/ (accessed 10 December 2018)).

${ }^{32}$ Here, we assume a distinction between Museums and Collections, regarding the latter as "'minor' exhibition structures, which do not necessarily provide systematic organisation or continuous public access" (Martino, "Musei e collezioni del patrimonio universitario. Indagine su un sistema culturale diffuso", cit.: 44).

${ }^{33}$ Julio Ruiz Berrio, "Historia y Museología de la Educación. Despegue y reconversión de los Museos Pedagógicos", Historia de la Educación. Revista Interuniversitaria 25 (2006): 271-90.

${ }^{34}$ Regarding the Italian context, see Juri Meda, "La conservazione del patrimonio storico-educativo: il caso italiano", in La historia de la cultura escolar en Italia y en España: presupuestos y perspectivas. Actas del I workshop Italo-Español de Historia de la Cultura Escolar. Berlanga de Duero, 14-16 de novembre de 2011, ed. Ana Badanelli (Macerata: Eum, 2013), 167-98.

${ }^{35}$ About the long-standing history of the museum in Rome, repeatedly dismembered and re-founded over time, see Carmela Covato, "Il Museo Storico della Didattica 'Mauro Laeng' dell'Università degli Studi Roma Tre", Ricerche di Pedagogia e Didattica 5, no. 2 (2010), doi:10.6092/issn.1970--2221/1912. In July 2018 the museum of Roma Tre University was reopened as the new Museum of the School and Education, under the guidance of Lorenzo Cantatore.

${ }^{36}$ About the decline of the nineteenth-century pedagogical museums in Italy, see Meda, "La conservazione del patrimonio storico-educativo: il caso italiano", cit. (here: 171-2 and 195-7). Regarding the emblematic parable of the National Pedagogical Museum in Rome, see Alberto Barausse, I maestri all'università. La scuola pedagogica di Roma. 1904-1923 (Perugia: Morlacchi, 2004), 35-43; and Alessandro Sanzo, Studi su Antonio Labriola e il Museo d'Istruzione e di Educazione (Roma: Edizioni Nuova Cultura, 2012).
} 
education. ${ }^{37}$ In the first decade of the twenty-first century, the research on the educational heritage received a strong boost and new university research centres were set up, which were characterised by the creation of new museums. These are the Centre for Documentation and Research of History of Textbooks and Children's Literature at the University of Macerata, which was established in 2004 and gave birth to the "Paolo and Ornella Ricca" School Museum in $2009 ;^{38}$ the Centre for Research and Documentation on History of Education in South Tyrol (Free University of Bolzano), which was established in Bressanone in 2007 and equipped with its own educational collection; ${ }^{39}$ and finally, the Centre for Documentation and Research on History of School Institutions, Textbooks and Children's Literature at the University of Molise, which established the Museum of School and Popular Education in Campobasso in 2012. ${ }^{40}$

These museums have the common denominator of having been strongly desired by groups of scholars actively involved in the most advanced lines of research on the school material culture, and who helped to save historical teaching materials and school objects which they considered as precious sources for their own research work. Today, however, those collections have been shown to own a new and interesting potential from the point of view of the third university mission.

In this sense, the evolutionary process of the museum in Macerata University is an emblematic example. The "Paolo and Ornella Ricca" School Museum was also born in the wake of the deep renewal which the History of Education experienced in Italy, especially after the 1990s, when the new international historiographical trends shifted the research focus from the history of pedagogical theories and ideas, onto the history of educational practices analysed through the lens of the new historiographical paradigm of school culture and, more specifically, of school material culture. ${ }^{41}$ In this first phase, the educational collections in Macerata mainly performed the functions of a real archive of sources. Since the establishment of the research centre in 2006,

\footnotetext{
${ }^{37}$ Giordana Merlo and Fabio Targhetta, "Il Museo dell'Educazione dell'Università di Padova: ragioni, finalità e criteri ispiratori delle collezioni e delle attività", in La práctica educativa. Historia, memoria y patrimonio, ed. Sara González et al. (Salamanca: FahrenHouse, 2018), 960-70.

${ }^{38}$ Anna Ascenzi and Elisabetta Patrizi, "I Musei della scuola e dell'educazione e il patrimonio storico-educativo. Una discussione a partire dall'esperienza del Museo della scuola 'Paolo e Ornella Ricca' dell'Università degli Studi di Macerata", History of Education \& Children's Literature 9, no. 2 (2014): 685-714.

${ }^{39}$ Annemarie Augschöll, "L'attività del Centro di ricerca e documentazione sulla storia della formazione in Alto Adige della Libera Università di Bolzano", in School Exercise Books. A Complex Source for a History of the Approach to Schooling and Education in the 19th and 20th Centuries, ed. Juri Meda, Davide Montino and Roberto Sani (Florence: Polistampa, 2010), 169-74.

${ }^{40} \mathrm{About}$ the research centre and the museum of Campobasso see the recent contribution by Rossella Andreassi, Alberto Barausse and Michela D'Alessio, "Museo de la escuela y de la educación popular de la Università de Molise, Campobasso, Italia", Cabás 16 (2016): 143-67.

${ }^{41}$ These lines were launched thanks to the seminal work by Julia, "La culture scolaire comme objet historique", in The Colonial Experience in Education: Historical Issues and Perspectives, ed. Antonio Nóvoa, Marc Depaepe and Erwin W. Johanningmeier, Monographic issue of Paedagogica Historica. Supplementary Series I (1995): 353-82; Marc Depaepe and Frank Simon, "Is there any Place for the History of 'Education' in the 'History of Education'? A plea for the History of Everyday Educational Reality inand outside Schools", Paedagogica Historica 30, no. 1 (1995): 9-16. Particularly significant for the development of new approaches in historical-educational research have been many other contributions of scholars too, but here we limit ourselves to mentioning some crucial works that appeared between the late 1990s and the early 2000s: Antonio Viñao Frago, "Por una historia de la cultura escolar: enfoques, cuestiones, fuentes", in Culturas y civilizaciones, III Congreso de la Asociación de Historia Contemporánea (Valladolid: Universidad de Valladolid, 1998), 167-83; lan Grosvenor, Martin Lawn and Kate Rousmaniere, eds., Silences and Images. The Social History of the Classroom (New York: Peter Lang, 1999); Juan Alfredo Jiménez Eguizábal et al., eds., Etnohistoria de la escuela: XII Coloquio nacional de historia de la educación (Burgos: Universidad de Burgos-SEDHE, 2003); Martin Lawn and lan Grosvenor, eds., Materialities of Schooling. Design, Technology, Objects, Routines (Oxford: Symposium Books, 2005); Agustín Escolano Benito, "La cultura material de la escuela", in La cultura material de la escuela. En el centenario de la Junta para Ampliación de Estudios, 1907-2007, ed. Id. (Berlanga de Duero: Ceince, 2007), 15-27; Pedro Luis Moreno, "La Historia de la Educación como disciplina y campo de investigación: renovación historiográfica, patrimonio y educación", in El largo camino hacia una educación inclusiva. La Educación Especial y Social del siglo XIX a nuestros días, ed. Reyes Berruezo and Susana Conejero, vol. 3 (Pamplona: Universidad Pública de Navarra, 2009), 141-51.
} 
the many important archival, library and object collections ${ }^{42}$ which began being donated to the university have allowed the launch of new lines of research: on school publishing, teachers' journals, children's literature and, finally, school heritage. In those years, the museum continued to develop as a university infrastructure able to innovate and to enhance historical-educational research, also acting as a space for meeting and exchange with colleagues from other countries, who came to Macerata in order to activate programmes of research internationalisation. Nevertheless, since the early years of its life the museum has increasingly become an important tool at the service of university teaching: a special teaching room for historical-educational disciplines and, at the same time, a sort of "history laboratory" where university students could work with primary sources (of documentary as well as material nature), apply tools and techniques for historical research and, therefore, acquire knowledge and skills which until then had been only conveyed by the theoretical study of a textbook. ${ }^{43}$

But, over the years, there has been a further change in the role and the functions of the museum, which has slowly begun to exercise a sort of retro-action on the system which had generated it. On the one hand, the museum has started to significantly have an impact on the same research practices of the historians of education by introducing new heuristic opportunities. ${ }^{44}$ As an embodiment of that field of studies which Agustín Escolano defined as the "cultura empírica de la escuela" $" 5$ and which, also in Italy, has been definitively recognised as one of the most innovative ambits of historical-educational research, ${ }^{46}$ the museum has paved the way for new lines of investigation: firstly, by expanding access to an ever-increasing variety of new documentary and material sources, and secondly, by providing the possibility to compare them with each other (at both a national and international level), to check their consistency (or discrepancy) with the official pedagogy and the school legislation, to examine the commercial mechanisms behind the production and the circulation of school materials or to rebuild the cultural evolution of the intangible heritage represented by school punishments, to give some examples. ${ }^{47}$ On the other hand, the museum gave an unprecedented transformative impulse to

${ }^{42}$ Marta Brunelli, "The 'Centre for Documentation and Research in History of Textbook \& Children's Literature' in University of Macerata (Italy)", History Of Education \& Children's Literature 4, no. 2 (2009): 441-52.

${ }^{43}$ See Ascenzi and Patrizi, "I Musei della scuola e dell'educazione e il patrimonio storico-educativo. Una discussione a partire dall'esperienza del Museo della scuola 'Paolo e Ornella Ricca' dell'Università degli Studi di Macerata', cit.; and Marta Brunelli, "The School Museum as a Catalyst for a Renewal of the Teaching of History of Education. Practices and Experiences from the University of Macerata (Italy)", Educació i Historia 26 (2015): 121-41 (here: 139-41).

${ }^{44}$ Starting from the suggestions received during the international symposium Image et pédagogie: perspectives internationales, held in Rouen in 2009, Fabio Targhetta has already highlighted these new heuristic perspectives in his contribution entitled: "I musei dell'educazione come risorsa per la ricerca", History of Education \& Children's Literature 5, no. 1 (2010): 421-31.

${ }^{45}$ In Italy, the growing interest in this ambit of investigation is evidenced by the recent Italian translation of the work by Agustín Benito Escolano, La cultura empirica della scuola. Esperienza, memoria, archeologia (Ferrara: Volta la Carta, 2016).

${ }^{46}$ Roberto Sani, "History of Education in Modern and Contemporary Europe: New Sources and Lines of Research", History of Education Quarterly 53, no. 2 (2013): 184-95.

${ }^{47}$ On the new research lines started by the group in Macerata and based upon the educational heritage (of tangible and intangible nature as well) see, for example: Juri Meda, Mezzi di educazione di massa. Saggi di storia della cultura materiale della scuola tra XIX e XX secolo (Milano: FrancoAngeli, 2016); Marta Brunelli and Juri Meda, "Gymnastics between School Desks: An Educational Practice between Hygiene Requirements, Health Care and Logistic Inadequacies in Italian Primary Schools (18701970)", History of Education Review 46, no. 2 (2017): 178-93; Anna Ascenzi and Marta Brunelli, "Accomplishing «The Silent Mission of Italian Women at War». The fascist 'Pedagogy of War' for Women: From the Kitchen Front to the War Garden", History of Education \& Children's Literature 11, no. 1 (2016): 497-522; Anna Ascenzi and Elisabetta Patrizi, "Inside School Lives: Historiographical Perspectives and Case Studies. Teachers' Memories Preserved at the Centre for Documentation and Research on the History of Schoolbooks and Children's Literature", Espacio, Tiempo y Educación 3, no. 1 (2016): 343-62; Anna Ascenzi, "«Italian beauties». The Italian cultural heritage and its landscape and natural resources in the school exercise books from the Fascist period to the World War II", History of Education \& Children's Literature 12, no. 1 (2017): 213-47; Juri Meda and Marta Brunelli, "The Dumb Child. Contribution to the study of the Iconogenesis of the Dunce-Cap", History of Education \& Children's Literature 13, no. 1 (2018): 41-70; Marta Brunelli, "Pour une histoire de la production industrielle de matériels didactiques en Italie entre la fin du XIXe et la première moitie du XXe siècle", in Education et culture matérielle en France et en Europe du XVle siècle a nos jours, ed. Marguerite Figeac-Monthus (Paris: Honoré Champion, 2018), 109-32; and Juri Meda, "Patentes e monopólios industriais: novas fontes para uma história da indústria escolar. Primeiras sondagens nos arquivos italianos (1880-1960)", in Cultura material escolar em perspectiva histórica: escritas e possibilidades, ed. Vera L. Gaspar da Silva, Gizele de Souza and Cesar A. Castro (Vitória: EDUFES Editora): 452-9. 
teaching practices: from initially being a laboratory space - where you actively acquire knowledge about the history of education, and practise skills of a historical-methodological nature - the museum consequently turned into a real Innovation Laboratory, where the promotion of the educational heritage has allowed the catalysis of innovative activities with a cultural, educational and social impact, both inside and outside academia.

\section{The Macerata School Museum and the challenges of the Third Mission}

In these years, the Museum in Macerata University has become the place for various experiments which have involved all the university historical-educational classes - of History of Education, History of Children's Literature and History of Special Education and have given life to new educational and cultural products and activities not only aimed at an internal public (i.e. university students and young researchers), but also targeted at different external audiences. These experiments made it possible to implement strategies aimed at innovating university teaching, in the first case; in the second case, they allowed the promotion of a deeper relationship with schools, families and the community in general. In this regard, the decision of the museum governance was strategic to develop a close collaboration with the classes of Heritage education and Museum education, which not only offered the theoretical and planning tools to enhance the heritage and to disseminate historical-educational knowledge to a wider public, but also paved the way for a fertile interdisciplinary dialogue with other fields of educational research: from General Pedagogy to Didactics, Special Education, Intercultural Education etc., as we will see.

In this regard, a crucial role in redesigning the museum's services was especially played by Heritage Education, which, in 1998, was defined by the Council of Europe not as a subject but as "a teaching approach based on cultural heritage" to be incorporated in school curricula. ${ }^{48}$ From such a perspective Heritage Education allows educators to look at historical-educational heritage not only as a treasure to discover (education in/ about heritage), but also as an opportunity to "develop people's knowledge of the dimensions of their own pasts" (education for heritage), and finally as a "learning tool" and a "medium for cross-curricular work" which "facilitates knowledge about heritage through the 'lens' of each subject area (education through heritage)". ${ }^{49}$ It is precisely this comprehensive approach - now further enhanced by the European Cultural Heritage Strategy for the 21st century of the Council of Europe ${ }^{50}$ - which facilitated the building of interdisciplinary links with other educational research branches, and the designing of activities able to connect the museum's educational heritage with current social issues. To concretely explain the potential of the approach

\footnotetext{
${ }^{48}$ Council of Europe, Recommendation No. R(98)5 of the Committee of Ministers to member states concerning Heritage Education. Adopted by the Committee of Ministers on 17 March 1998 at the 623rd meeting of the Ministers' Deputies, https://rm.coe.int/ (accessed 28 April 2019).

${ }^{49}$ See Tim Copeland, European Democratic Citizenship, Heritage Education and Identity (Strasbourg: Council of Europe, 2006), here: 17-21, and, more recently, Nicole Gesché-Koning, Research for CULT Committee-Education in Cultural Heritage (Brussels: European Parliament-Policy Department for Structural and Cohesion Policies, June 2018), here: 1618, http://www.europarl.europa.eu/thinktank/en/document.html?reference=IPOL_STU(2018)617486 (accessed 28 April 2019).

${ }^{50}$ Council of Europe, Recommendation No. R(2017)1 of the Committee of Ministers to member States on the European Cultural Heritage Strategy for the 21st century. Adopted by the Committee of Ministers on 22 February 2017 at the 1278th meeting of the Ministers' Deputies, https://rm.coe.int/ (accessed 28 April 2019).
} 
adopted, we will briefly illustrate four examples, selected from the activities implemented in recent years, and which we consider emblematic of how a university museum of the history of education can achieve the objectives outlined for the Third Mission.

\subsection{The museum and the challenges of inclusion: the programme "Lesson in the dark"}

The first example illustrates how a university museum of the history of education can become a seat of experimentation in innovative educational products and technological tools aimed to offer answers to the real needs of inclusive education. ${ }^{51}$ We refer to the initiative entitled Lesson in the dark, which was born from the scientific cooperation between the Museum and the Chair of Special Education with the aim to create a series of technological-educational supports useful to break down the sensorial and cognitive barriers in the school museum. The outcomes of the work - still in progress - are yearly presented to a large public during the Macerata University for Inclusion festival, which the University has organised with the local municipality and some national associations supporting people with disabilities ${ }^{52}$ since 2017. In that year, a research group on special education and museum accessibility was established, which involved academic scholars, doctoral students as well as university students with disabilities and highfunctioning autism (Asperger's syndrome), who played a crucial role in designing and testing activities. One of the first outcomes was the prototype for a video-virtual tour of the museum equipped with a facilitated audio-description, ${ }^{53}$ which was designed to be accessible to people with cognitive disabilities, individuals with autism spectrum disorder, visitors with limited knowledge of the Italian language or low education and, finally, blind and partially sighted visitors. This tool - under a progressive implementation with subtitles and video-recordings in sign-language interpretation, which will make its content accessible to deaf people too - is the first of a series of technological aids and educational Apps which will be realised in the years to come.

In addition, on the last day of the festival (which takes place on 3 December, the same date as the European Day of Disabled People) the Museum provides the training workshop Lesson in the dark, targeted at pre-service and in-service teachers interested in working with children who have a variety of disabilities such as visual impairments. During the workshop, after discussing the most important findings and the critical issues of special education history, the participants experience a situation of temporary

\footnotetext{
${ }^{51} \mathrm{An}$ issue, that of inclusion and accessibility, which educational museums also have to address. See, in this regard, Pablo Álvarez Domínguez, "Accesibilidad e inclusión en espacios museísticos. Algunas reflexiones críticas desde los Museos de Educación", in Accesibilidad y museos: divulgación y transferencia de experiencias, retos y oportunidades de futuro, ed. Ana M. Galán-Pérez and Elena López Gil (Sevilla: Asociación de Museólogos y Museógrafos de AndalucíaJunta de Andalucía, 2017), 139-46.

${ }^{52}$ The partners of the initiative are Anffas-National Association of Families with Persons with Intellectual and/or Relational Disabilities, and the Community of Capodarco in Fermo, a non-profit association working nationwide in assisting sick and disabled as well as poor and abandoned people.

${ }^{53}$ In drafting the facilitated audio-description, we referred to the European standards for making information easy to read and understand created within the EU project Pathways, https://easy-to-read.eu/it/ (accessed 10 December 2018), on the one hand. On the other, the guidelines for the audio-description in museums have been used: in particular those edited by the Royal National Institute for the Blind (RNIB), Museums, Galleries and Heritage Sites: Improving Access for Blind and Partially Sighted People. The Talking Images Guide (2003); and the Guidelines for Verbal Description written within the project Art Beyond Sight, coordinated by the non-profit organisation Art Education for the Blind, http:// www.artbeyondsight.org/handbook/acs-guidelines.shtml (accessed 10 December 2018).
} 
sensory deprivation in order to explore places and objects in the museum with the help of the same methodologies that they will have to use, as teachers, to support students with disabilities. This workshop represented one step of a more complex training course in which participants also made short audio-descriptions and easy-to-read texts concerning objects and exhibits of the museum, which - after being tested with the volunteers of the associations for blind and cognitively disabled people - will become the new accessible captions of the School Museum. The results achieved in the first two editions have been very positive both in terms of participation (all workshops had a full house from an average of 60 attendees) and in terms of educational impact. In 2018 all participants compiled a post-workshop survey from which emerged an appreciation of the teaching methods implemented, in which the transmission of historical-educational contents (history of disability and history of inclusion) was intertwined with the participatory and simulative approach of the workshop; finally all the respondents highlighted the strong points and innovative aspects to reinforce, in order to improve the 2019 edition. $^{54}$

In our opinion, this event is a concrete example of the Third Mission, which demonstrates how a museum can become a laboratory wherein to apply the knowledge produced by universities to generate social and educational value with regard to the very current and pressing issues of inclusion and cultural accessibility. Through the collaboration with the social partners represented by national and local associations (Social Engagement), the academic research results (in the fields of Special Education, Museum Education and History of Special Education) have been shared and applied to create specific workshops for teacher training and updating (Continuing Education) and educational technology tools to be released in the near future (Innovation and Technology Transfer). ${ }^{55}$

\subsection{The School Museum and the festival "Macerata Tells Stories"}

In these years, the School Museum has increased its visibility outside the academy by starting various collaborations with local authorities, cultural associations and local festivals which demonstrate how the museum's know-how can be transferred to collaborations with external partners and generate economic value. One of these partners is represented by the literary festival Macerata Racconta (Macerata Tells Stories), which, since 2011, has been offering the city a rich agenda of conferences, a publishing exhibition, a competition for secondary and high-school students (with the Prize for the Young) as well as educational and training workshops for schools and teachers. Since 2016, the School Museum has been a partner of the Festival and has been commissioned to provide technical and scientific advice in managing the educational activities. In 2017 from from the collaboration with the local associations "Contesto" and "La luna a dondolo" the new initiative The Young Judges was born,

\footnotetext{
${ }^{54}$ About the genesis and implementation of the project see: Anna Ascenzi and M. Brunelli, "Lezione al buio. Percorsi inclusivi al Museo della Scuola 'Paolo e Ornella Ricca'", in In azione. Prove di inclusione, ed. Catia Giaconi and Noemi Del Bianco (Milano: FrancoAngeli, 2019), 67-82. About the evaluation of the 2018 edition see now: Benedetta Indirli, "Vedere con la mente. La 'Lezione al buio' al Museo della Scuola 'Paolo e Ornella Ricca': dal progetto alla valutazione" (Master's Thesis in History of Education (Supervisor: Prof. Marta Brunelli), University of Macerata, 2019).

${ }^{55}$ Such educational-technological tools, after being tested and perfected, can be released on the market as free or paid Apps - depending on the involvement of profit or non-profit partners.
} 
consisting in engaging a jury of 29 young "strong readers" - selected from local primary and secondary schools - who gathered in the Museum rooms, wrote the evaluation criteria, read the tales in competition and chose the winning tale, which was then performed as a theatrical event open to all the citizens during The Night of Tales.

On the occasion of the 2019 edition, for the first time the university students who attend the classes of History of Education, History of Children's Literature and, in particular, students enrolled in the new Workshop "Paolo and Ornella Ricca" School Museum were also involved in the Festival. ${ }^{56}$ In this way university students can develop their educational projects from ideation to implementation, i.e. following an educational pathway which will lead them from studying theory (in lecture rooms), to actively interacting with the Festival's organisers and their partners (cultural associations, non-profit institutions, local companies and services providers), on the one hand and, on the other, with the Festival's public such as schools, teachers and other audiences. ${ }^{57}$ In addition to innovating university teaching, the activity described above has generated economic value since the didactic research developed in the Museum has turned into a scientific consulting service commissioned by the university (Third party activity), through which the university museum designed and provided non-institutional training activities (Continuing Education) and cultural events for a wide public (Outreach and Public Engagement). Finally, it is worth mentioning that the activity promoted a new entrepreneurial competence in university students on education courses, who experienced the opportunity to present their projects for possible future professional collaborations with external partners, different from the usual school world.

\subsection{Experiments in Public History and Citizen History}

Over the last three years the Museum has been developing a series of initiatives which can be regarded - according to the aforementioned ANVUR definition of the "cultural and social Third Mission" - as public goods with a cultural and educational content (Knowledge Transfer) and with a content of civic awareness (Public Engagement) as well.

Especially in the last school year, the School Museum has offered schools the opportunity to develop specific educational projects functional to the educational planning of teachers and relevant to the educational needs of students. Among the proposals received, a local high school asked to carry out research on a historicaleducational topic, which allowed students to directly work on the museum's primary sources and to use historical-educational research methodologies. The choice fell on the history of an ancient outdoor school, which was originally located in the middle of a public garden in Macerata and whose memory is still partly alive in the oldest citizens. This initiative is part of a project of participatory history, which the museum had

\footnotetext{
${ }^{56}$ About this new educational planning Workshop - launched in 2016, and linked to the history of education courses see footnote 68 .

${ }^{57}$ Since 2016 the editions co-organised with the University have recorded a good audience with an average of 850 participants every year, including pupils and teachers involved in the competition, students' families participating in the public events (theatrical events and exhibitions) and participants in training workshops. Source: Annual report of the Museum (years: 2016, 2017 and 2018).
} 
launched through social networks in 2016 by inviting people (through the research methodology of crowdsourcing) ${ }^{58}$ to report, collect and share sources such as vintage photos, original documents and autobiographical stories concerning this old school and the story of its protagonists, teachers as well as pupils. ${ }^{59}$

Now the new research carried out by high-school students has allowed, on the one hand, the addition of further sources - e.g. unpublished archival sources, oral interviews from students' families and local inhabitants - through which it will be possible to reconstruct a missing fragment of the history and the collective memory of the town. ${ }^{60}$ On the other hand, this initiative has promoted academic knowledge outside university, by disseminating historical-educational contents and by sharing with teachers and pupils the specific methodologies of Digital History (Knowledge Transfer). ${ }^{61}$ In a broader meaning, the project has actively involved students, families and senior citizens in the gathering of the individual and collective memories of the community and, thus, in the production of historical knowledge (Citizen Science and Public History). ${ }^{62}$ Besides, the project has allowed the promotion of the value of the educational heritage in general as a collective cultural asset and as a foundation of the communal history and identity (Civic Awareness and Public Engagement).

\subsection{The European researcher's night}

Among the cultural activities of Public Engagement, there are those aimed at making university museums accessible to special public groups (such as families, the elderly, migrants, visitors with special needs, etc.) as well as reaching new and potential visitors, even organising external events. In this respect, an important opportunity for outreach is represented by the European Researchers' Night, the yearly initiative which - now a very established event in the collective imaginary and an inevitable appointment for all the European universities involves thousands of researchers and European institutions with the aim of bringing the general public closer to scientific culture and research professions. ${ }^{63}$

\footnotetext{
${ }^{58}$ The neologism crowdsourcing was coined to describe participatory research projects developed thanks to the volunteer contributions of Internet users, who are invited to gather sources and information on a large scale. Wellknown to public historians, the methodology of crowdsourcing has taken great advantage of the new information technologies, and it is now widely used especially in the field of digital history. For a reflection on the status of Italian research, compared to the international scene, see Serge Noiret, "Digital History 2.0", in L'histoire contemporaine à l'ère numérique. Contemporary History in the Digital Age, ed. Frédéric Clavert and Serge Noiret (Bruxelles: Peter Lang, 2013), 155-90; and, by the same author, "Storia pubblica digitale", Zapruder. Storie in movimento 36 (2015): 9-23.

${ }^{59}$ Marta Brunelli, "La comunicación y la interpretación del patrimonio educativo en los museos: espejo y reflejo de una disciplina en transformación", in Espacios y Patrimonio Histórico-Educativo, ed. Pauli Davila and Luis M. Naya (San Sebastián: Erein, 2016): 79-95.

${ }^{60}$ The research carried out by the high-school students has been illustrated in the digital monograph: Massimo Bracci, ed., C'era una volta una scuola di legno [Once upon a time there was a wooden school]. By the classes III B and III C (Macerata: Classic Lyceum G. Leopardi, school year 2017/2019), http://classicomacerata.gov.it/ (accessed 28 April 2019).

${ }^{61}$ The project described is part of the doctoral research carried out by Eleonora Rampichini (Tra memoria della scuola e valorizzazione del patrimonio. II caso del Museo della Scuola «Paolo and Ornella Ricca» dell'Università di Macerata. Research supervisor: Prof. Marta Brunelli). The implemented methodologies and the evaluation of the outcomes of the project will be illustrated in the final thesis.

${ }^{62}$ See now: Marta Brunelli, "«Non-Places» of School Memory. First Reflections on the Forgotten Places of Education as Generators of Collective School Memory: Between Oral History, Public History and Digital History", History of Education \& Children's Literature 14, no. 1 (2019): 49-72.

${ }^{63}$ As known, the European Researchers' Night is an initiative promoted and co-funded by the European Commission since 2005.
} 
The School Museum also took part in the 2018 edition and proposed a new way to use museum collections based on a narration through images, which was suitably set up in a location in the old town. In the wake of the most innovative trends in exhibit design, we wanted to create an immersive and participatory event which - halfway between digital projection and shadow puppetry - allowed the visitors themselves to become the real protagonists of this experience. So, we projected some school images on a large projector screen and, behind it, we placed objects and desks from the museum collections, among which the visitors could move undisturbed and give life themselves to situations and characters from the individual and collective school imaginary: from the strict teacher, to the diligent schoolgirl, up to the ever-present naughty and mischievous "dunce" and so on. The goal of the event was to symbolically open the museum doors to all the citizens and, at the same time, to involve them by inviting them to "enter" the virtually recreated museum, and become an active part of the exhibition. ${ }^{64}$

The event has achieved the result of introducing the School Museum to new potential audiences (Outreach) ${ }^{65}$ and made the activities of the historical-educational research known to a large public (Dissemination). At the same time, it allowed us to provoke in citizens a new awareness of the value of educational heritage and to transmit to them the importance of preserving their own old school objects, also by donating to the museum (Civic Awareness and Social Engagement). ${ }^{66}$ In conclusion, this initiative has made it possible to project the public image of university in the social sphere and to create a bridge between the institution and the everyday people, so that they know that scientific research is not confined within university walls, but it can have a cultural sense and a social value for each individual.

\section{First conclusions and prospects}

We decided to illustrate some of the initiatives carried out in recent years, since we believe that they highlight the specific potential that university educational museums may have, both in the wake of current international processes of revitalisation of university heritage and museums, and in the light of the new objectives of the University Third Mission. As we have seen, it is evident that these cultural institutions can be able to reach both internal and external publics by providing innovative products and services, which have been realised after establishing fruitful interdisciplinary collaborations with colleagues in other educational sciences. Such collaborations have not only greatly increased the museum's potential, but have also broken down the barriers of a sort of marginalisation into which the historical discipline seemed in danger of falling and, finally, have made the historians of education "to be heard by other members of the community of educational researchers". ${ }^{67}$ After showing the potential educational, cultural and social impact which these museum's activities

\footnotetext{
${ }^{64}$ The event was conceived and realized by the team of the museum in collaboration with the Communication Office of the University.

${ }^{65}$ In the two weeks following the event, the number of accesses to the museum's Facebook page increased by $18 \%$ as well as the total number of contacts by phone/email, which has led to a $4 \%$ growth in requests for museum visits, particularly by families. Source: monthly statistics of the Facebook page (see also the Annual report of the Museum, year 2018).

${ }^{66}$ In 2012 the Museum launched the campaign "Dona la tua memoria" (Donate your memory), which allows not only citizens, such as former pupils and former teachers, but also schools to donate their old school objects and other material. See the dedicated webpage, http://museodellascuola.unimc.it/dona-la-tua-memoria/ (accessed 8 October 2018).

${ }^{67}$ Joyce Goodman and lan Grosvenor, "Educational Research: History of Education: A Curious Case?", Oxford Review of Education 35, no. 5 (2009): 601-16 (here: 612).
} 
could develop, and will develop more and more in the years to come, today the Paolo and Ornella Ricca School Museum has become one of the initiatives of the Third Mission developed by the Department and strongly supported by the University: an objective that, until a few years ago, seemed difficult to meet especially in a university with a strong vocation in the fields of humanities and social sciences, and where the majority of scholars - being essentially engaged in pure research - would hardly have thought to transfer knowledge with the aim of increasing the well-being of society from a social, cultural or even economic perspective. On the contrary, in the last years the school museum in Macerata University has revealed part of its potentialities and received increasing attention both inside and outside university: a small museum supposedly destined to exclusively act within a specialised scientific-disciplinary field (the history of education) - has shown itself to be able to dialogue with an everincreasing number of public and private stakeholders, and to develop unprecedented lines of interdisciplinary planning, but without ever betraying the nature of its collections or the specificity of the historical-educational research.

A first result of these development policies is that a new perception of the School Museum (and of the historical-educational disciplines as well) has gradually taken root in the collective imaginary, inside and outside the university. Today, in fact, the School Museum has been accredited to offer curricular internship opportunities for all the students in Macerata University, ${ }^{68}$ and to impart a specific 60-hour workshop focused on Heritage Education planning intended for students of the Master's Degree in Teacher Training. ${ }^{69}$ For these reasons, the museum is no longer seen exclusively as a history of education workshop but rather as a place where future educators can further develop their knowledge and their skills by planning educational programmes and services with an interdisciplinary approach and, in sum, can acquire a truly all-round training which combines History of Education with Didactics, Heritage Education, Special Education, Educational Technology and so on. This change of perception is clearly witnessed, on the one hand, by the continuous growth of the Workshop participants who increased from $7 \%$ to $20 \%$ of the students enrolled in the degreecourse per year; ${ }^{70}$ and, on the other hand, by the substantial increase in the applications for new master's theses in History of Education, in which the historical-educational research is supplemented with educational planning and experimentation in the School Museum.

In short, what is increasingly emerging is a new model of a university school museum which we have above defined as a permanent Innovation Laboratory: a crucial "hub" which provides chances of scientific intertwining between different areas of academic research as well as opportunities for exploring new creative ways of interacting with public and private stakeholders in the outside world; a "window" through

\footnotetext{
${ }^{68}$ Students can carry out a curricular internship, whose duration varies from a minimum of 150 hours to a maximum of 250 hours, and which is developed in accordance with an educational project agreed between each student and his/ her academic supervisor. The internship is recognised with the attribution of a number of CFUs in a measure established by the Class Council of each degree course.

${ }^{69}$ Initially offered as extra-curricular activity, in the academic year 2017-2018 the School Museum Workshop was definitely included as an elective course in the curriculum of the Master's degree (5 years) in "Primary education sciences" (LM-85bis), which qualifies graduates to teach in pre-primary and primary schools.

${ }^{70}$ At the University of Macerata, the admission quota for the aforementioned degree LM-85bis cannot exceed the number of 230 students per academic year.
} 
which the historians of education can show the results of the research they carry out to a large public or even share their own scientific expertise and tools with the community; or, again, a place in which to design and implement new educational-technological tools which can respond to pressing social issues. Nevertheless, such an Innovation Laboratory can work as a special lecture-room in which to capitalise on the most advanced museum activities, with the aim of innovating university teaching and making it more effective in providing students with new competences and key skills - thereby creating a virtuous circle of knowledge exchange between university and society.

Of course, these results are neither immediate nor easy to achieve, but require medium-long-term planning due to the complexity of the processes to be started and the partnerships to be consolidated, both outside and inside university. However, we think that there is no end to the possibilities of growth that a university museum can develop, and the above-illustrated activities represent only part of a huge potential that remains still mostly unexplored, especially for university School Museums.

As explained above, in fact, it cannot be denied that educational museums must face additional critical issues, in addition to the structural problems that affect all university museums (and mainly consisting in an endemic lack of financial resources, adequate offices and dedicated staff on the one hand, and, on the other hand, in the objective difficulty for academics to devote themselves to museums by taking their time and intellectual resources away from the already pressing activities of the First and the Second Mission).

In our opinion, in fact, the most critical issue is represented by what eminent scholars have already highlighted, and is closely related to the "academic marginalisation" 71 of the History of Education within the university curriculum, a real "confinement from which it is difficult to emerge". ${ }^{72}$ This situation is determined by the fact that the History of Education, in spite of the evident vitality of this discipline (witnessed by the birth of new societies and specialised journals as well as the emerging new lines of research), still seems to have to struggle to affirm its strategic position within educational research. As a result, the History of Education is usually perceived as a discipline with a mere cultural function, if not only propaedeutic to the study of other disciplines which are considered far more relevant for the training of future teachers. ${ }^{73}$ It is such a vision that keeps on reinforcing the perception of our discipline as a real clay pot forced to travel among the iron pots represented by Pedagogy, Didactics, Educational Technologies or Psychology, and it is also the reason behind the progressive dismantling of university chairs of History of Education in favour of Pedagogy chairs - a phenomenon we are now witnessing in Italy.

In contrast, we believe that highlighting and promoting the cultural and social value of the educational heritage - whether it is preserved in a university museum, or spread through the territory (as local or private museums and, finally, as museums arranged by/within schools) - undoubtedly offers historians of education the opportunity to keep updated with the latest lines of the international research in the field, as is demonstrated

\footnotetext{
${ }^{71}$ Susanne Spieker and Angelo Van Gorp, "Capacity Building and Communitas in the History of Education", Paedagogica Historica 52, no. 6 (2016): 768-883.

${ }^{72}$ Simonetta Polenghi and Gianfranco Bandini, "The History of Education in its Own Light: Signs of Crisis, Potential for Growth", Espacio, Tiempo y Educación 3, no. 1 (2016): 3-20 (here: 4).

${ }^{73}$ Gary McCulloch, The Struggle for the History of Education (Abingdon: Routledge, 2011), here: 98-111.
} 
by the advance of the research in those countries, like Spain or France, where the museology of education has a long tradition ${ }^{74}$ and where the scientific associations of educational heritage are strongly consolidated. ${ }^{75}$ On the other side, the educational heritage preserved and managed by universities constitutes a springboard for fulfilling the objectives of the Third Mission, and an opportunity "to achieve inclusive, integrated heritage based education towards a sustainable development", as recommended by the European policies. ${ }^{76}$

Last but not least, strengthening this strategic position of the university museums of educational heritage means also strengthening the role of the historian of education. As a specialist in contents, in fact, the historian can manage and enhance at best such a specific heritage and - with the active support of other experts of educational research (in primis of heritage education) - can turn it into a wealth and a resource for courses, department and university as a whole. The Museum in Macerata University has just begun to exploit this advantage, demonstrating an unexpected potential for the purposes of the Third Mission and, at the same time, gaining an increasing visibility for History of Education as a specialised knowledge, which - through the study and the promotion of the heritage - can express a new and exclusive specificity within the academic community.

\section{Disclosure statement}

No potential conflict of interest was reported by the authors.

\section{Notes on contributors}

Anna Ascenzi is Full Professor in History of Education in the Department of Education, Cultural Heritage and Tourism at the University of Macerata. Acting Director of the Centre for Research on History of Textbooks and Children's Literature (CESCO), since 2012 she has been also directing the "Paolo and Ornella Ricca" School Museum in the same university. Her research covers topics in history of education and children's literature (especially gender education, nation-building, history of subject teaching in schools) as well as on the role of educational heritage as a change agent to foster innovation in higher education. Currently she is president of the Italian Society for the Study of Educational Heritage (SIPSE). She is co-author (with Roberto Sani) of the recent work: Storia e antologia della letteratura per l'infanzia nell'Italia dell'Ottocento (2 vols., 2017-2018). She is a member of the executive council of the journal History of Education \& Children's Literature.

\footnotetext{
${ }^{74}$ For the Spanish situation, see the recent works: Pablo Álvarez Domínguez, Paulí Dávila Balsera and Luis María Naya Garmendia, "Education Museums: Historical Educational Discourse, Typology and Characteristics: The Case of Spain", Paedagogica Historica: International journal of the history of education 53, no. Extra 6 (2017): 827-45; Pablo Álvarez Domínguez, coord., Los museos pedagógicos en España: entre la memoria y la creatividad (Gijón: Trea, 2016). About the French scenario see: Michel Mieussens and Claude Bouhier, "Un réseau qui doit s'organiser: les 170 musées de l'école en France", in La France savante [online], dir. Arnaud Hurel (Paris: Éditions du Comité des travaux historiques et scientifiques, 2017): 366-79, doi:10.4000/books.cths.2796; and Première Rencontre francophone des musées de l'école. Actes (Futuroscope, Chasseneuil-du-Poitou: Canopé éditions, 2018), https://www.reseau-canope.fr/musee/fileadmin/ user_upload/Premiere-Rencontre-Francophone-Musees-Ecole-Actes.pdf (accessed 8 October 2018).

${ }^{75}$ As is known, many scientific associations of the historical-educational heritage have been set up, from the 1980s to now, both in Europe (France, Switzerland, Spain, Portugal, United Kingdom, Greece) and outside Europe (Argentina, Chile, Brazil and Canada), just to mention the most representative cases. Such a scenario was enriched, in 2017, with the birth of the AMNEPE-Amis du musée national de l'éducation, des musées de l'école et du patrimoine éducatif (in France) and the SIPSE-Società Italiana per lo Studio del Patrimonio Storico-Educativo (in Italy).

${ }^{76}$ Gesché-Koning, Research for CULT Committee-Education in Cultural Heritage, cit. (here: 39 ).
} 
Marta Brunelli is Associate Professor in General and Social Education in the Department of Education, Cultural Heritage and Tourism at the University of Macerata. She is member of the Executive Board of the Centre for Documentation and Research on History of Textbooks and Children's Literature (CESCO), and coordinator of educational services of the "Paolo and Ornella Ricca" School Museum. Her work focuses on heritage education, with a special regard to school museums as educational resources. Her recent books are: L'educazione al patrimonio storico-scolastico (2018) and Heritage Interpretation. Un nuovo approccio per l'educazione al patrimonio (2014). Since 2006 she has been the editorial manager of the journal History of Education \& Children's Literature.

Juri Meda is Associate Professor in History of Education in the Department of Education, Cultural Heritage and Tourism at the University of Macerata. In the same university he is a member of the Executive Board of the Centre for Documentation and Research on History of Textbooks and Children's Literature (CESCO) and of the "Paolo and Ornella Ricca" School Museum. Currently he is secretary of the Italian Society for the Study of Educational Heritage (SIPSE). He is the author of articles and scientific contributions on the history of education. His recent books are: School Memories. New Trends in the History of Education (2017), edited with Cristina Yanes Cabrera and Antonio Viñao, and Mezzi di educazione di massa. Saggi di storia della cultura materiale della scuola tra XIX e XX secolo (2016).

\section{ORCID}

Anna Ascenzi (D) http://orcid.org/0000-0002-2209-4584

Marta Brunelli (D) http://orcid.org/0000-0001-9218-8642

Juri Meda (D) http://orcid.org/0000-0003-0054-3622 